\title{
EXPLORING TEACHING TECHNIQUES USED IN TEACHING READING COMPREHENSION BY ENGLISH TEACHERS AT MADRASAH ALIYAH PASANGKAYU
}

\author{
Aisyah Kahar Putri, Rofiqoh, Mukrim \\ Universitas Tadulako, Sulawesi Tengah, Indonesia \\ Email: aisyahkputry@gmail.com, rofiqoirwankari@gmail.com, \\ mukrim.tamrin@gmail.com
}

\begin{abstract}
This research was aimed at finding out the teaching techniques used in teaching reading comprehension by English teachers from four Madrasah Aliyah at Pasangkayu Regency. MAN Pasangkayu, MA DDI Pasangkayu, MA DDI Kasoloang and MA DDI Darul Ulum. This research applied mix method approach. The respondents of this research were 8 English teachers. The instrument for collecting the data was a questionnaire and interview. Quantitative data were collected and analyzed in the first phase of the research and qualitative data were collected in the second phase. The results reveal that the English teachers use several techniques in teaching reading comprehension such as Scanning Technique, Skimming Technique, SQ3R, Speed Reading, Detailed Reading Strategy, and Collaborative Strategic Reading. The result of the interview showed that the teachers tended to use the Scanning-Skimming technique and SQ3R compared to other techniques. According to them, the Scanning-Skimming technique were two techniques that were very effective for students to use when they did English exams, especially reading texts, they find it easier to get information from a reading text. Meanwhile, SQ3R is a technique that is very good for the benefit of reading intensively. The teachers at Madrasah Aliyah Pasangkayu Regency to upgrade in teaching reading are only some of them who have attended seminars/webinars or training from related agencies or schools. As for their efforts in improving their reading teaching skills, only a few of them were creative to learn independently to find references, hold study groups, review journals, and download videos about teaching reading techniques. Every teacher needs to be more creative for the learning process can be successful.
\end{abstract}

Keywords: teaching technique; reading comprehension

Received: 2021-09-20; Accepted: 2021-10-05; Published: 2021-10-20

\section{Introduction}

Reading is one of the language skills which is essential to be mastered by students because reading is an essential factor that influences one's activity in communication. Reading is regarded as a receptive skill that interprets codes into ideas. Reading

How to cite:

E-ISSN:

Published by:
Putri. A.K., Rofiqoh \& Mukrim (2021) Exploring Teaching Techniques Used In Teaching Reading Comprehension By English Teachers At Madrasah Aliyah Pasangkayu. Syntax Literate: Jurnal Ilmiah Indonesia, 6(10). http://dx.doi.org/10.36418/ Syntax-Literate.v6i10.4360 2548-1398

Ridwan Institute 
becomes essential for everyone to increase their knowledge. It provides rich sources of vocabulary and grammar. It is a practice media for readers to train their English.

Reading does not occur in a vacuum. It is done for a purpose to achieve and during reading, the reader processes the text about the purpose (Eko, 2020). To be a good reader, the learner must learn how to comprehend and understand the passage. Reading is very important for English learners because reading can enlarge their knowledge, vocabulary, and information from reading enable them to get a complete understanding of the text.

However, for some students reading English tasks is not easy. Sometimes they do not understand the content of the text or they cannot get information from the text. It happens because of several problems that must be overcome by an English teacher who expects their students to be able to read English text with good comprehension.

Comprehension in reading means understanding what is being read. Many students are strong at recognizing words in print but struggle with making meaning from what they read. According to (van den Broek \& Espin, 2012), reading comprehension is a complex interaction among automatic and strategic cognitive processes that enables the readers to create a mental representation of the text. Comprehension depends not only on characteristics of the reader, such as prior knowledge and working memory, but also on language processes, such as basic reading skills, decoding, vocabulary, sensitivity to text structure, inference, and motivation.

The goal of teaching and learning is to produce and comprehend language that is spoken and written. Some people think that a successful English learner is a person who can speak English fluently. They do not know that a person who is said a successful English learner is a person who must master all English skills.

In the teaching of reading, teachers must master a variety of techniques that can be adjusted to classroom conditions. According to (Faidah, Fauziati, \& Suparno, 2019) technique encompasses the actual moment-to-moment practices and behaviors that operate in teaching a language according to a particular method. In other words, the technique is classroom practice done by the teacher when presenting a language program. This is the way the classroom activities are integrated into lessons and used as the basis for teaching and learning.

One of the most important aspects of teaching reading techniques is to help students to develop their understanding of a text as well as enrich their stock of vocabulary. The teachers are required to be more creative to select appropriate techniques to make students understand the texts easily.

Many researchers have conducted studies about teaching reading techniques. For instance, (Abu-Ubaida, Amina, Aishatu, \& Abubakar, 2017) exploring the teaching of reading skills in Nigerian Secondary Schools. The study delved into the conceptual meaning of reading skills and make an epitomical overview on the categories of reading skills thus, skimming, scanning, intensive reading, and extensive reading as majors among others. Being able to read fluently depends on several different skills. Therefore, it is the teachers' role and responsibility to provide, plan and teach an effective reading 
program that will enable the learner to become a skillful reader. A good teacher is capable of unleashing the natural reading wisdom of students, and indeed minimizing the reading difficulties of students with disabilities. Similar research was also done by (Apsari \& Yana, 2015) about teachers' techniques and problems in teaching reading. This study is aimed at exploring teachers' techniques in teaching reading comprehension at one senior high school in Bandung Barat and investigating the problems that the teachers encountered in teaching reading. Her study revealed that the respondents used the teaching reading comprehension techniques in three reading stages: prereading, while-reading, and post-reading stages. In the pre-reading stage, they applied Previewing technique and Vocabulary Instruction Technique; Pre-Reading Questions and Brainstorming Technique, and discussing text type. Then, in while reading stage, they used Question-Answering Techniques, Vocabulary Instruction Technique, Recitation, and Reading aloud. In the post-reading stage, they conducted reviewing techniques and follow-up strategies. The data also indicated that in teaching reading comprehension, there were four problems encountered by the respondents in teaching reading: lack of students' vocabulary mastery, lack of motivation in reading, students were not used to read a lot regularly, and teaching time allocation. Concerning the findings, it is recommended for English teachers to select an appropriate technique in teaching reading which is relevant to the students' needs.

Given the importance of using various techniques in teaching reading as discussed above, the researcher is interested to conduct a study with the topic about what techniques do English teachers apply in teaching reading, why do they tend to use particular techniques as a reference in teaching reading and how do they upgrade themselves in teaching reading.

\section{Research Method}

1. Research Design

In conducting the research, the researchers used a mixed-method research design. This method focused on combining between quantitative method and the qualitative method. It focuses on collecting, analyzing, and mixing both quantitative and qualitative data in a single study or series of studies. The basic assumption is that using qualitative and quantitative methods in a study can better understand or answer a research question than using only one design.

Based on the classification of the mixed method, the researchers chose to use an explanatory type design, which is included in the sequential model. This type of design carries out firstly quantitative research then followed by doing qualitative research. (Creswell \& Creswell, 2017) proposes that the explanatory design is a twophase mix methods design, the overall of this design is that qualitative data help explain or build upon initial quantitative results.

2. Instruments of Data Collection

This research used two kinds of instruments to collect the data; a questionnaire and an interview. 
a. Questionnaire

The questionnaire consisted of 14 items. 8 items were related to the techniques applied in teaching reading by the English teachers, and 6 items were about how they upgraded themselves teaching in reading. The questionnaire was made online by using a google form and distributed to the English teachers (see appendix 1). The data were collected through a five-item Likert Scale questionnaire survey. They are always, often, sometimes, rarely, and never. (Members et al., 2004)

b. Interview

The interview was used to support the data from questionnaires. A semistructured interview was applied to the respondents. It consisted of 7 questions to find out more about teaching techniques used in teaching reading comprehension by English teachers and reasons for choosing a particular teaching technique used. The interview was conducted after all respondents answered the questions on the questionnaire.

\section{Result and Discussion}

A. The Result of Questionnaire Data

Descriptive statistics are used to explain the questionnaire data for each research statement. The data described is the frequency value of the research data distribution. In this section, the researcher firstly presents the result of teachers' responses emphasizing techniques used by teachers in teaching reading as presented in table 4.1-4.8. Following them, she further presented tables 4.9 - 14 which focus on exploring how they upgrade themselves regarding techniques in teaching reading.

A. Frequency Distribution Based on Using Different Methods / Techniques in Each Reading Lesson

Table 1

Frequency Distribution of Question 3

\begin{tabular}{ccc}
\hline & Frequency & Percent \\
\hline Always & 1 & 12.5 \\
Often & 3 & 37.5 \\
Sometimes & 2 & 25.0 \\
Rarely & 2 & 25.0 \\
Total & 8 & 100.0 \\
\hline
\end{tabular}

Source: Primary data processed by SPSS, 2020

Based on the result of the table 1, it can be inferred that most teachers "often" used different methods/techniques in each reading lesson. Meanwhile, other teachers chose "sometimes" and "rarely" with two of them respectively. One teacher opted to respond "always".

B. Frequency Distribution Based on Finding References to the Latest Reading Learning Methods / Techniques 
Table 2

Frequency Distribution of Question 5

\begin{tabular}{ccc}
\hline & Frequency & Percent \\
\hline Always & 2 & 25.0 \\
Often & 4 & 50.0 \\
Sometimes & 2 & 25.0 \\
Total & 8 & 100.0 \\
\hline
\end{tabular}

Source: Primary data processed by SPSS, 2020

Regarding statement 2, most of them responded "often" and "Rarely", with 3 responses respectively. 2 other teachers answered "often". Meanwhile, other teachers chose "always" and "sometimes".

C. Frequency Distribution Based on Using "Scanning" Techniques in Teaching Reading

Table 3

Question Frequency Distribution 6

\begin{tabular}{ccc}
\hline & Frequency & Percent \\
\hline Always & 2 & 25.0 \\
Often & 4 & 50.0 \\
Sometimes & 2 & 25.0 \\
Total & 8 & 100.0 \\
\hline
\end{tabular}

Source: Primary data processed by SPSS, 2020

Based on the table 3, it is found that the most answers provided by the teachers were "often" in using scanning technique responding. While the least answers were "always" and sometimes".

D. Frequency Distribution on Using "Skimming" Techniques in Teaching Reading

Table 4

Frequency Distribution Question 7

\begin{tabular}{ccc}
\hline & Frequency & Percent \\
\hline Often & 3 & 37.5 \\
Sometimes & 4 & 50.0 \\
Never & 1 & 12.5 \\
Total & 8 & 100.0 \\
\hline
\end{tabular}

Source: Primary data processed by SPSS, 2020

Based on the table 4, four out of eight teachers responded "sometimes" for using the skimming technique in teaching reading The other 3 teachers chose the "often' statement, and one teacher answered "never".

E. Frequency Distribution Based on Using the "Sqrrr (Survey, Question, Read, Recite, Review)" Technique in Teaching Reading 
Table 5

Frequency Distribution of Question 8

\begin{tabular}{ccc}
\hline & Frequency & Percent \\
\hline Often & 4 & 50.0 \\
Sometimes & 2 & 25.0 \\
Rarely & 1 & 12.5 \\
Never & 1 & 12.5 \\
Total & 8 & 100.0 \\
\hline
\end{tabular}

Source: Primary data processed by SPSS, 2020

Based on the table 5, it was found that the most answers provided by the teachers were "often" in responding about usingSQ3R. While the least answers were "rarely" and "never".

F. Frequency Distribution on Using the "Speed Reading " Technique in Teaching Reading.

Table 6

Frequency Distribution of Question 9

\begin{tabular}{ccc}
\hline & Frequency & Percent \\
\hline Always & 1 & 12.5 \\
Often & 3 & 37.5 \\
Sometimes & 2 & 25.0 \\
Rarely & 1 & 12.5 \\
Never & 1 & 12.5 \\
Total & 8 & 100.0 \\
\hline
\end{tabular}

Source: Primary data processed by SPSS, 2020

Based on the table above, it is found that using the "Speed Reading" technique in teaching reading answers the most is "often". Meanwhile, the answers to the least are "always", "rarely", and "never".

G. Frequency Distribution on Using "Detailed Reading" Techniques in Teaching Reading.

Table 7

Frequency Distribution of Question 10

\begin{tabular}{ccc}
\hline & Frequency & Percent \\
\hline Always & 1 & 12.5 \\
Often & 3 & 37.5 \\
Sometimes & 2 & 25.0 \\
Never & 2 & 25.0 \\
Total & 8 & 100.0 \\
\hline
\end{tabular}

Source: Primary data processed by SPSS, 2020

In terms of using "detailed reading" technique, the most answer responded by teacher is "often", in which 3 of them chose it. Respectively, two teachers responded to "sometimes" and "never". Meanwhile, the other one teacher answered "always". 
H. Frequency Distribution on Using "Collaborative Strategic Reading" Techniques in Teaching Reading.

Table 8

Frequency Distribution Question 11

\begin{tabular}{ccc}
\hline & Frequency & Percent \\
\hline Always & 3 & 37.5 \\
\hline Sometimes & 2 & 25.0 \\
\hline Never & 3 & 37.5 \\
\hline Total & 8 & 100.0
\end{tabular}

Source: Primary data processed by SPSS, 2020

Table 8 display the frequency of teachers using the "collaborative strategic reading" technique in teaching reading. From their responses, it was found that the responses"never" and "always" had similar number of teachers who chose them. The rest two of them answered "sometimes"

Having presented the teachers' responses on using techniques/method in teaching reading, in the following tables of 4.9-4.14, the researcher described the teachers' responses on ways of developing themselves with various techniques used in teaching reading, as presented below.

I. Frequency Distribution on Participating in Training Organized by Related Services

\section{Table 9}

Frequency Distribution of Question 12

\begin{tabular}{ccc}
\hline & Frequency & Percent \\
\hline Often & 4 & 50.0 \\
Sometimes & 1 & 12.5 \\
Rarely & 1 & 12.5 \\
Never & 2 & 25.0 \\
Total & 8 & 100.0 \\
\hline
\end{tabular}

Source: Primary data processed by SPSS, 2020

Table 9 displays teachers' involvement in training in order to develop their teaching technique in reading. The data shows that four teachers (50\%) answered that they "often" attend the training. Two of them responded "never" and the other two teachers respectively chose "rarely" and sometimes.

J. Frequency Distribution on Reviewing Journals About Reading Teaching Methods.

Table 10

Frequency Distribution of Question 13

\begin{tabular}{ccc}
\hline & Frequency & Percent \\
\hline Often & 5 & 62.5 \\
Sometimes & 2 & 25.0 \\
Never & 1 & 12.5 \\
Total & 8 & 100.0 \\
\hline
\end{tabular}


Source: Primary data processed by SPSS, 2020

In addition to attending training, table 10 displays teachers' responses frequency in reviewing journals about teaching methods of reading. Most of them, 5 teachers or $62.5 \%$, answered that they "often" did it. The other 2 teachers responded "sometimes" and 1 teacher answered "never".

K. Frequency Distribution on Creating Study Groups to Discuss Reading Teaching Methods

Table 11

Frequency Distribution of Question 14

\begin{tabular}{ccc}
\hline & Frequency & Percent \\
\hline Always & 1 & 12.5 \\
Often & 1 & 12.5 \\
Sometimes & 1 & 12.5 \\
Rarely & 4 & 50.0 \\
Never & 1 & 12.5 \\
Total & 8 & 100.0 \\
\hline
\end{tabular}

Source: Primary data processed by SPSS, 2020

In terms of making study groups to discuss teaching methods of reading, table 11 revealed that most of the teachers answered "rarely" engaged in such activity. Meanwhile, 4 other teachers, each of them responded to "always", "often", "sometimes", and "never".

L. Frequency Distribution on Downloading Reading Teaching Videos

Table 12

Frequency Distribution Question 15

\begin{tabular}{ccc}
\hline & Frequency & Percent \\
\hline Always & 3 & 37.5 \\
Often & 3 & 37.5 \\
Sometimes & 1 & 12.5 \\
Rarely & 1 & 12.5 \\
Total & 8 & 100.0 \\
\hline
\end{tabular}

Source: Primary data processed by SPSS, 2020

Table 12 describes teachers' responses frequency in developing their knowledge and skill of teaching reading through downloading the reading teaching video. It was shown from the data that the option"always" and "often" shared similar number of teachers answered them (3 teachers). Meanwhile the option "sometimes" and "rarely" were also chosen by 1 teacher respectively. This data suggests that learning from downloading videos about teaching reading becomes a preferred way in developing their teaching reading techniques.

M.Frequency Distribution on Reading References Related to Reading Teaching 
Table 13

Question Frequency Distribution 16

\begin{tabular}{ccc}
\hline & Frequency & Percent \\
\hline Always & 3 & 37.5 \\
Often & 3 & 37.5 \\
Sometimes & 2 & 25.0 \\
Total & 8 & 100.0 \\
\hline
\end{tabular}

Source: Primary data processed by SPSS, 2020

Based on the table above, it can be seen that reading references related to teaching reading becomes a common practice among teachers. It was shown that out of 8 teachers, each response of "always" and "often" was chosen by 3 teachers. The other 2 teachers answered "sometimes".

N. Frequency distribution take part in seminars/webinars related to the latest English language teaching

Table 14

Frequency Distribution Question 17

\begin{tabular}{ccc}
\hline & Frequency & Percent \\
\hline Always & 1 & 12.5 \\
Sometimes & 6 & 75.0 \\
Never & 1 & 12.5 \\
Total & 8 & 100.0 \\
\hline
\end{tabular}

Source: Primary data processed by SPSS, 2020

The table 14 depicts the frequency of teachers attending seminars/webinars related to the latest English language teaching technique. The most response from teachers was $t$ "sometimes" in which 6 of them chose this option. Only one teacher responded to "always" and also "never".

\section{Discussion}

In helping students to get success in learning English, teachers need a good technique. Similary, teachers need various teaching techniques if they want to succeed in their teaching. By using varied teaching techniques, the learning process will be more enjoyable, meaningful, and successful.

Based on the result of the study, the reading teaching techniques most often used by English teachers at MA Pasangkayu Regency were Scanning, Skimming and SQ3R techniques. It can be said that reading teaching techniques used by English teachers at MA Pasangkayu Regency is still dominated by Scanning-Skimming techniques (Elismawati, 2016). Both of the strategies help the students to read in a more focused and efficient way. Therefore, Skimming-Scanning strategy is an accelerated reading strategy to quickly looking for the idea and specific information of the text. In addition, (Maxwell, 1972) stated that scanning is the ability to locate specific facts and details 
quickly. Skimming-scanning is regarded as a desirable reading skill and it is taught in most developmental reading courses because it helps students to get information easily in efficient way. Meanwhile SQ3R is one of techniques that help the students to understand the reading texts. This technique is divided into 5 steps; survey, questions, read, recite, and review. As (McNamara, 2007) argues that the generic strategies of SQ3R are methodically applied in all texts with little or no consideration of the nature of text content.

Based on the result of the study, it was shown that the reading teaching techniques most often used by English teachers at MA Pasangkayu Regency were Scanning, Skimming and SQ3R techniques.

Based on result, the data showed that indicator "always" got 2 the frequency got $25 \%$. "often" got 4 then the percentage got 50 the indicators "sometimes" 2 then percentage $25 \%$. It was found that the most answers provided by the teachers were "often" in using scanning technique responding. While the least answers were "always" and sometimes". The teacher often applied the scanning method in learning which aimed to increase the level of students' understanding of reading comprehension. Teachers also aimed to improve reading skills. If students used the Scanning reading technique, they would be looking for some possible copywriting information. Many students tried to read every word of every sentence they read. By practicing the Scanning reading technique, a person could learn to read to understand the reading text in a faster way. On the other hand, students also quickly finished reading and become excited about reading other materials so that we really mastered more information and ideas.

Based on the table, the data showed that indicator "often" got 3 then the percentage got $25 \%$ the indicators "sometimes" got 4 then percentage $50 \%$. Then never 1 percentages got $12,5 \%$. It was known that the frequency distribution based on using the skimming technique in teaching reading has the most answers is "sometimes". Meanwhile, the answer is "never" the "least". The teacher sometimes used the skimming technique than the scanning because in scanning, the teacher allowed students to read quickly in order to get certain information on the text. Reading fast is not able to mean just reading very fast, but set the pace eye view proportionally on each word depending on the weight the proposition of the word. On the other hand, in the skimming technique, the teacher used only when students needed to find the main idea of each text. Skimming referred to the process of speed reading to get the main idea. The main idea must be sought in order to get an overall understanding of the content of a passage.

Based on the result, the data showed that indicator "often "got 4 the frequency got $50 \%$. "Sometimes "got 2 then the percentage got $25 \%$ the indicators "never" and "rarely" got 1 then percentage 12,5\%. It was found that the most answers provided by the teachers were "often" in responding about using SQ3R. While the least answers were "rarely" and "never". The use of the SQ3R method in this study obtained the highest questioner results on indicator "often" meaning that many teachers often used 
this method. This method that helped students think about the text easily so that students gain understanding the first time they read the text. The SQ3R method could also improve students' reading abilities and skills in reviewing all answers to the questions that have been given. This method also helped in improving the memory of reading comprehension so that students difficult easily forget the essence of the reading.

Based on the results of interviews with indicators of What The English Teachers' Techniques Apply in Teaching Reading at MA Pasangkayu, shows that the teacher as informant 1 implies that in applying skimming and scanning it is done in doing English exam questions, finding the main idea or outline of the entire reading, in Analyze the supporting detail reading as well when analyzing the Phonics method, Active Reading Style, and Detailed Reading. whereas for the teacher as informant 2, the teacher uses the SQ3R technique in analyzing stages or repeats and accompanied by chronological stages, is considered appropriate as a method to improve reading comprehension, requires students to be active in surveying or investigating, asking questions, reading, strengthening reading acquisition, and repeating self-understanding, and apply this technique in class in finding the structure or purpose on the text.

The tendency for English teachers used the three techniques above because according to them the Scanning and Skimming technique are two techniques are very effective for students to use when they do English exam, especially reading texts, they found easier to get information from a reading text. A previous studied was conducted by (Diaz \& Laguado, 2013) also affirms that the use of skimming and scanning techniques can enhance reading comprehension and improve students' reading skills. Further data form observations and semi-structured interviews revealed that these techniques also changed their students' perceptions towards reading to positive point of views, motivated the students to read better.

Meanwhile SQ3R is a technique that is very good for the benefit of reading intensively and rationally, SQ3R includes 5 steps, namely survey, question, read, recite, review. The SQ3R method is a learning method that requires students to be active in surveying or investigating, asking, reading, strengthening reading acquisition, and repeating self-understanding. It can be said that there are many teaching techniques that English teachers can apply in teaching reading comprehension.

Indeed, teachers who are said to be professionals are teachers who master many teaching techniques that are applied to achieve the learning goals. (Nahlawi, 1989) emphasized that one of the teacher's requirements is to master the teaching method. In addition, a good teacher is a teacher who masters the ways of teaching the subject matter that he teaches to his students. (Handayani, n.d.), an expert on Islamic education in Indonesia, emphasizes that one of the requirements to become a teacher is to have knowledge. One of them is the knowledge of techniques to teach the subject matter he teaches. (Syahputra, 2021), an expert on Islamic education in Indonesia, also emphasized that teachers must be experts or have the ability to teach. Of course, what is meant is the ability to use teaching techniques to deliver the subject matter he teaches to his students. 
In choosing a technique for reading learning, the teacher should sort out the methods that will help students understand the content, concepts, and terms of reading comprehension learning. In addition, teachers must also consider the purpose of using certain skills or techniques to help teachers implement them in an effective way.

Based on the results of interviews with informants 1 stated the reasons for choosing skimming techniques in teaching reading for reading with the aimed of seeking certain information quickly and precisely. The purpose of skimming tehnique in reading is basically to gain a lot comprehension from reading quickly. There is no point being able to read with fast but unable to understand the content of the reading adequately. Otherwise, If you can read with full understanding, but speed slow reading, it can be said to be reading inefficiently. Therefore, a good and equal balance between reading speed and reading comprehension. The second is to quickly find out the whole book and comprehensive, while the time available is very limited. Then the purpose is to look for content points or main ideas designed to improve ability to read quickly by capturing important words in a sentence and leave other unimportant words without will lost the slightest understanding. Many words in a sentence, a paragraph, or a book, then there will always be word important and main which is the subject of thoughts and other words is an auxiliary word which, if omitted, will not be eliminated the meaning. Seeing the advantages of this Special Technique, it is expected students can be more efficient in spending time in reading as well in study.

Based on the second informant explained the reason for choosing the SQ3R technique is to get a detailed and detailed reading understanding because this technique is divided into 4 steps, namely Survey-Question-Read-Review-Review.

"I chose this technique because in my opinion the benefits of this technique are as follows:

1. The task approach through reading the text can make students be more confident

SQ3R can help the student have a good self-confident. Having high selfconfidence in students can help achieve achievement and better learning outcomes. That way there will be a process of change in students not only in results learning but also on behavior and attitudes students, namely courage, activeness, and actualization of students themselves during the learning process teach. According to (Brown, 2000), self-confidence is probably the most pervasive aspect of any human behavior. It could easily be claimeded that no successful cognitive or affective activity can be carried out without some degree of self-confidence, self-confidence knowledge of yourself, and belief in your own capabilities for activity.

a. On the other hand, the students that a weak in self-confident, will low interest in learning and the result in the low score. (Wright Peter Wright, Mark J. Kroll, 1996) (Kanza, Allard, \& Berube, 2016) pointed out some characteristics of students with low self-confidence which are: they are fearful of change: they are worried and fear about what can happen in the future. They have negative attitudes about their abilities and they tend to be re-active rather than pro-active. $b$. They are pessimistic and tend to see the glass as half empty: they consider that the 
others are responsible for what happen to them. They did not tried to make any effort or to be active persons and they always have belief that bad things will happen. c. They have difficulty communicating what they really want from life: they have no obvious idea about their aimed or objectives in life. Generally, they just think about generalities such as: to be rich, thin, beautiful and so on. For them, everything is difficult and they cannot reach it. d. They want to please others more than be true to themselves: they like to make others happy and satisfied more than to tried discovering their potential and to change their attitudes. They are insecure and are drawn to others who also see themselves as victims: they have destructive believes and never tried to be successful in their life and learning. They easily give up when they face problems.

2. Helping student concentration in finding answers

The facts on the ground show various problems that indicate that the concentration of student learning is still low. Several factors influence the level of concentration Student learning is a student characteristic and a learning strategy used by the teacher in presenting a lesson. SQ3R technique helps students concentrate in learning. Students read actively in order to find answers to questions that have been arranged. In this case, active reading also means reading that is focused on paragraphs which are thought to contain the answers that are thought to be relevant to the above question.

3. This method can help students to focus on the parts that are most difficult in reading, if a question is not can be answered or understood, students can identify the difficulty and get the answer.

Q in the SQ3R method is a question. At this stage it really helps students find answers to the most difficult parts after conducting several surveys. When facing a reading, students ask yourself questions about related matters with reading. These questions can guide them in understanding reading and directing the mind to the content of the reading that will be entered the students are active. They just follow what is said the author. The teacher can criticize and question what is said the author while looking at the evidence later. The SQ3R method is a method can encourage students to read and focus on text reading effectively. This method can make it easier for students to obtain information in each reading source.

4. Train to provide answers to questions about the material

Reading using the SQ3R method has profit with pre-arranged questions about what to expect read can arouse the reader's curiosity to seek important (relevant) answers. This is in the end will increase understanding and accelerate mastery the entire book. One measure that students understand reading is by stating the answer or evidence and presenting it to himself in mumbling, audible, or written notes and by rearranging random sentences into paragraphs coherent.

5. Help prepare notes in the form of questions and answers"

After the students have finished reading the book as a whole, review it important things that have been read. students tried to find the important parts that 
are need to remember again, especially things that have been marked or underlined. This repetition will help your memory to clarify the understanding of the reading, it also helps find important things that may have been missed before. Besides, students also get the whole book content.

Regarding the indicators in questioner of using the different technique in teaching reading, the researcher also got the results from asking the informants as follows:

Frequency Distribution Based on Finding References to the Latest Reading Learning Methods / Techniques. The result showed that indicator "always" got 2, and the percentage got 25\%. "Often" got 4 the frequency got $50 \%$. Sometimes got 2 then the percentage got $25 \%$. Regarding statement 2, most of them responded "often" and "Rarely", with 3 responses respectively. 2 other teachers answered "often". Meanwhile, other teachers chose "always" and "sometimes". The teacher often looked for resources or additional references to increase knowledge in the use of learning techniques in English classes, especially reading. This aimed to improve teacher competence in accordance with government regulations and school principals. For teachers who sometimes looked for additional knowledge about teaching techniques in reading, they had reasons that they were still busy and had not been able to develop their knowledge.

Based on the interview with informant 1 about The Way the Teachers Upgrade Themselves Regarding Teaching Techniques in Teaching Reading,

States that:

"As a teacher it is necessary to develop teaching techniques in teaching reading by being an observer in other learning, the teacher must understand technology well, and the teacher must actively participate in training and seminars related to the development of teaching and learning".

From informant 1's answer it can be explained how the teacher develops teaching technique skills as follows:

1. As an observer in other class in reading teaching and learning process

According to (Hidayah \& As-shodiq, 2020) potential can be referred to as strength, energy, or hidden abilities that are owned and have not been optimally utilized. Self-potential is referred to here as a hidden strength in the form of physicality, character, interests, talents, intelligence and values that are contained within the self but have not been utilized and processed.

As an observer in an English language teaching, the teacher can compare how well a technique can be received by students. Then compare it with other techniques in other classes or techniques that the teacher as an observer does. In order that it can increase the teacher's insight in mastering some English teaching techniques especially reading.

2. The teacher must be understand in technology

The teacher must be a modern teacher who understands technology in order to support the renewal of science and the development of teaching techniques. Not only 
relying on books, whiteboards and markers but being able to apply learning materials using computers, projectors and the internet. This is likely to generate different learning interests with different techniques that keep users in the classroom or study room. The use of computers and projectors not only writing but combined with images (visuals), sound (audio, music, instruments) and real examples of video.

3. Joining some teaching training

One of the ways to develop the potential of teachers in using English language learning techniques is to attend several trainings related to the development of teaching techniques. In this case the school also conducts training at least once a month. Good training requires evaluation as feedback for previous training. If necessary, schools can make modifications to the results of the training evaluation. Thus, the training that is intended for teachers is very useful in performance improvement and performance management itself. (Hanafi, 2011).

This current research found that the English teachers at MA Pasangkayu Regency upgrade their teaching reading techniques through attending seminars / webinars or receiving training from related agencies or schools, albeit only some did so. Additionally, only a few of them were creative to learn independently to find references, hold study groups, review journals and download videos about teaching reading techniques. Indeed, every teacher needs to be more creative in order the learning process can be successful. Because a good teacher not only gives the learning material to the students, but also she/he gives advice, guidance, motivation, so that the learning process can be interested to the students.

According to informant 2, one of his efforts in understanding teaching and learning skills in reading learning is

"Always actively follow the development of technical techniques by following media such as browsing from the internet, besides always conducting peer teaching between teachers."

Informant 2 said that in developing reading teaching techniques there are two ways as follows:

a. Following the development of English language teaching techniques, especially reading by browsing from the internet

According to La Rose (Nurafiati, Rahayu, \& Sugiharto, 2021) states that people who want to develop their potential, namely. Have a flexible attitude. Dare to make changes totally for improvement. Have a sense of responsibility. Receive criticism from outside suggestions. Optimistic spirit and not easily give up. The last, learn constantly searching information related to things that enrich the knowledge. The sophistication of technology makes it a place for teachers to seek knowledge as wide as possible, this modern era, the world is in this technology means that there is nothing that is not found on the internet. All information can be obtained through this. Teachers must understand and be able to understand technology well so that they can use it as a platform to develop talents and competencies as well as interviewers about good learning techniques. 
b. Conducting peer teaching between teachers on a regular

Regarding the indicator in questioner The Way the Teachers Upgrade Themselves Regarding Teaching Techniques in Teaching Reading. The researcher also got the results from asking the informants as follows:

1. Frequency Distribution on Participating in Training Organized by Related Services

Based on the results questioner, the result showed that indicator" often" got 4 the frequency got $50 \%$. "Sometimes" and "rarely" got 1 then the percentage got $12.5 \%$. Indicator "never" got 2 and the percentage got $25 \%$. It was known that the frequency distribution based on participating in the training held by the relevant agencies, the most answers is "often". While the answers to the least are "sometimes" and "rarely". 50\% of the teachers in this study often tooked part in English language learning both outside and inside the school. They were enthusiastic in order to improve the ability to teach English so that they can teach well and can be received by students.

2. Frequency Distribution on Reviewing Journals about Reading Teaching Methods.

Based on the result of questioner, the result showed that indicator "often" got 5 the frequency got $65.5 \%$. "Sometimes" got 2 then the percentage got $25 \%$. "Never" got 1 and percentage got $12.5 \%$. It was known that the frequency distribution is based on reviewing journals about teaching methods of reading. Most answers was "often". Meanwhile, the answer was "never" the least. On the results of the questionnaire, the results of this indicator were the highest results, namely teachers often reviewed English journals by $65 \%$. This result was good enough that more than half of the teachers have tried to develop the ability to improve the quality of English language teaching by increasing the number of exercises

3. Frequency Distribution on Creating Study Groups To Discuss Reading Teaching Methods

Based on the result questioner, the result showed that indicator "always", "often", "sometimes" and "never" got 1, and the percentage got 12.5\%. "Rarely" got 4 the frequency got $50 \%$. It was known that the frequency distribution is based on making study groups discuss teaching methods of reading the most answers was "rarely". Whereas the least answers were "always", "often", "sometimes", and "never". In forming learning groups related to discussing English language teaching methods, the majority of teachers rarely did that. They still used the old method, namely individual learning in the conventional way. This needs to be changed, teachers should use group learning more often to stimulate student creativity and how to cross-legged properly.

4. Frequency Distribution on Downloading Reading Teaching Videos

Based on the results of questioner, the result showed that indicator" always" got 3, and the percentage got 37,5\%. "Often" got 3 the frequency got 37,5\%. "Sometimes" and" rarely" got 1 then the percentage got $12,5 \%$. It was known that 
the frequency distribution based on downloading the reading teaching video most answers are "always" and "often". While the answers to the least are "sometimes" and "rarely". There were the same results on indicators often and always, namely $37.5 \%$, so it was evident that teachers often perform referrals via video to support teachers' competence and expertise in teaching. They tried hard to arrange good English and can help students understand reading well.

5. Frequency Distribution on Reading References Related to Reading Teaching

Based on the result of questioner, the result showed that indicator "always" got 3, and the percentage got 37.5\%. "Often" got 3 the frequency got $37.5 \%$. "Sometimes" got 2 then the percentage got $25 \%$. It was known that the frequency distribution was based on reading references related to teaching reading most answers were "always" and "often". Meanwhile, the answer was "sometimes". Indicators often and sometimes got the same result, namely $37.5 \%$ in distributing references to teaching English. This is related to sharing the references they have with other teachers so that they can share knowledge with other teachers who are still lacking in improving the competence of learning English.

6. Frequency distribution take part in seminars/webinars related to the latest English language teaching

Based on the results of questioner, the result showed that indicator "always" and "never" got 1, and the percentage got 12, 5\%. "Sometimes" got 6 then the percentage got $75 \%$. It was known that the frequency distribution was based attend seminars/webinars related to the latest English language teaching most answer was sometimes. Meanwhile, the answer to the least are "always" and "never". The percentage of indicators on teacher participation in teaching training seminars was very high, which was $75 \%$. This was still a task that must be done immediately, namely treading to attend an English education seminar. If you don't find seminar in the area, the teacher can take part in online seminars that have been provided much.

The teacher's role is very influential as educators and teachers. Basically, teaching is an attempt to create a cognition or environmental system that supports and enables the learning process to take place. (Carbonell et al., 2008) teaching is an activity in which the teacher conveys the knowledge or experience that is owned by students. Teaching aimed so that the knowledge conveyed can be understood by students. Teachers are an important element, teachers as the spearhead of formal education, need to be equipped with abilities that can encourage creativity. The teachers must master the subject matter steadily and develop a learning model that is relevant. Therefore, it is hoped to the English teachers at MA Pasangkayu Regency tried to improve their reading teaching techniques or strategies. There are many references about teaching techniques or strategies that English teachers can apply in teaching reading skills. According to (Coştu, 2008) Teaching strategy should be developed for teachers in order to provide students to make connections between their knowledge of science and 
related everyday situations. It can be concluded that the teacher's teaching strategy is the teacher's effort in teaching so that students easily understand the material being studied. The use of variations in teaching techniques or strategies in learning activities is necessary in creating learning process to be effectively and efficiently. Thus, teachers are obligated to master teaching techniques so that learning goals can be achieved.

\section{Conclusions}

Based on the research results that have been described in the previous chapter, the conclusions of this study are:

The teacher as informant 1 implies that in applying skimming and scanning it is done in doing English exam questions, finding the main idea or outline of the entire reading, in Analyze the supporting detail reading as well when analyzing the Phonics method, Active Reading Style, and Detailed Reading. whereas for the teacher as informant 2, uses the SQ3R technique in analyzing stages or repeats and accompanied by chronological stages, is considered appropriate as a method to improve reading comprehension, requires students to be active in surveying or investigating, asking questions, reading, strengthening reading acquisition, and repeating self-understanding, and apply this technique in class in finding the structure or purpose on the text. The data from the questionnaire shows the indicators "often" have the highest percentage, so it means that the teacher often uses the techniques in teaching reading in class.

The reasons for the teacher using the technique in teaching and learning reading, it shows that the teacher as an informat 1 states that the use of teaching techniques is very important because to gain a lot comprehension from reading quickly find out the whole book and comprehensive, to focus on the parts that are most difficult in reading, to provide answers to questions about the material, and to Help preparing notes in the form of questions and answers. on the other hand, the teacher as informant 2 stated that the reason for using techniques in teaching reading is to make students be more confident, and can help students to focus on the parts that are most difficult in reading. The results of the questionnaire show Frequency Distribution Based on Finding References to the Latest Reading Learning Methods / Techniques is the highest score 50\%. It means the teacher often enrich the references in teaching.

The Way the Teachers Upgrade Themselves Regarding Teaching Techniques in Teaching Reading. Informant 1 explained that there were 3 ways to do it, namely As an observer in other class in reading teaching and learning process, The teacher must be understand in technology, and joining some teaching training. While informant 2 explained the two ways that were taken in developing competency, namely following the development of English language teaching techniques, especially reading by browsing from the internet, and conducting peer teaching between teachers on a regular. The questionnaire, it shows that the highest percentage and frequency reaches in the "often" indicator, especially in the questionnaire, which reads Frequency distribution take part in seminars / webinars related to the latest English language teaching which 
Aisyah Kahar Putri, Rofiqoh, Mukrim

reaches a frequency of $75 \%$. This shows that teachers actively attend seminars in order to develop their potential in the use of English language teaching techniques. 


\section{BIBLIOGRAFI}

Abu-Ubaida, S., Amina, U. U., Aishatu, A. B., \& Abubakar, U. U. (2017). Exploring The Teaching Of Reading Skills In Nigerian Secondary Schools. Iosrjournal Of Research \& Method In Education (Iosr-Jrme). E-Issn, 2320-7388. Google Scholar

Apsari, Yanuarti, \& Yana, Yana. (2015). Teachers'techniques And Problems In Teaching Reading. Jurnal Ilmiah P2m Stkip Siliwangi, 2(2), 217-233. Google Scholar

Brown, H. Douglas. (2000). Principles Of Language Learning And Teaching (Vol. 4). Longman New York. Google Scholar

Carbonell, Eudald, De Castro, José M. Bermúdez, Parés, Josep M., Pérez-González, Alfredo, Cuenca-Bescós, Gloria, Ollé, Andreu, Mosquera, Marina, Huguet, Rosa, Van Der Made, Jan, \& Rosas, Antonio. (2008). The First Hominin Of Europe. Nature, 452(7186), 465-469. Google Scholar

Coştu, Bayram. (2008). Learning Science Through The Pdeode Teaching Strategy: Helping Students Make Sense Of Everyday Situations. Eurasia Journal Of Mathematics, Science And Technology Education, 4(1), 3-9. Google Scholar

Creswell, John W., \& Creswell, J. David. (2017). Research Design: Qualitative, Quantitative, And Mixed Methods Approaches. Sage Publications. Google Scholar

Diaz, Sindy, \& Laguado, Juan Carlos. (2013). Improving Reading Skills Through Skimming And Scanning Techniques At A Public School: Action Research. Opening Writing Doors Journal, 10(1), 133-150. Google Scholar

Eko, Yunianto Agung Prihananto. (2020). Improving Character Based Reading Comprehension By Applying Pqrst Model Of The Tenth Year Students Of Smk Muhammadiyah 2 Klaten Utara In Academic Year Of 2019/2020. Universitas Widya Dharma Klaten. Google Scholar

Elismawati, Elismawati. (2016). Classroom Interaction Analysis In The Efl Speaking Class: A Study At English Department Of Iain Imam Bonjol Padang. Polingua: Scientific Journal Of Linguistics, Literature And Language Education, 5(1), 2532. Google Scholar

Faidah, Ririn Tutik, Fauziati, Endang, \& Suparno, Suparno. (2019). Teachers'beliefs On Multiple Intelligence Based English Teaching For Young Learners. Exposure: Jurnal Pendidikan Bahasa Inggris, 8(1), 60-72. Google Scholar

Hanafi, Abdul Halim. (2011). Metode Penelitian Bahasa: Untuk Penelitian. Tesis Dan Disertasi. Jakarta: Diadit Media. Google Scholar 
Handayani, Dita. (N.D.). Multiple Intelligences Learning-Based For Islamic Teaching In The Elementary School. Google Scholar

Hidayah, Nurul, \& As-Shodiq, Mohammad Ja'far. (2020). Strategi Kepala Sekolah Sebagai Pelatih Di Sma Negeri 1 Srengat Blitar. Joiem (Journal Of Islamic Education Management), 1(2). Google Scholar

Kanza, Rene Epunza, Allard, Christian, \& Berube, Michel. (2016). Cardiac Findings On Non-Gated Chest Computed Tomography: A Clinical And Pictorial Review. European Journal Of Radiology, 85(2), 435-451. Google Scholar

Maxwell, Martha J. (1972). Skimming And Scanning Improvement: The Needs, Assumptions And Knowledge Base. Journal Of Reading Behavior, 5(1), 47-59. Google Scholar

Mcnamara, Danielle S. (2007). Reading Comprehension Strategies: Theories, Interventions, And Technologies. Psychology Press. Google Scholar

Members, Committee, Eagle, Kim A., Guyton, Robert A., Davidoff, Ravin, Edwards, Fred H., Ewy, Gordon A., Gardner, Timothy J., Hart, James C., Herrmann, Howard C., \& Hillis, L. David. (2004). Acc/Aha 2004 Guideline Update For Coronary Artery Bypass Graft Surgery: Summary Article: A Report Of The American College Of Cardiology/American Heart Association Task Force On Practice Guidelines (Committee To Update The 1999 Guidelines For Coronary Artery Bypass Graft Surgery). Journal Of The American College Of Cardiology, 44(5), 1146-1154. Google Scholar

Nahlawi, Alabdurrahman. (1989). Principles And Methods Of Education In Families In Schools And Communities.

Nurafiati, Suastika, Rahayu, Tandiyo, \& Sugiharto, Harry Pramono. (2021). Strategy For Strengthening Character Education In Physical Education Learning At Makassar City Elementary Education Level. Journal Of Hunan University Natural Sciences, 48(6). Google Scholar

Syahputra, Afrizal El Adzim. (2021). Metode Dakwah Perspektif Quraish Shihab (Analisis Terhadap Qs. Al Nahl: 125-128 Dalam Tafsir Al Misbah). Google Scholar

Van Den Broek, Paul, \& Espin, Christine A. (2012). Connecting Cognitive Theory And Assessment: Measuring Individual Differences In Reading Comprehension. School Psychology Review, 41(3), 315-325. Google Scholar

Wright Peter Wright, Mark J. Kroll, And John Parnel. (1996). Strategy, Management, Concept, And Case. Google Scholar

\section{Copyright holder:}

Aisyah Kahar Putri, Rofiqoh, Mukrim (2021) 
First publication right:

Syntax Literate: Jurnal Ilmiah Indonesia

This article is licensed under:

(c) (†) (?) 